\title{
Articles
}

\section{The L2 Motivational Self System: A Replication Study}

\author{
Leander S. Hughes \\ Saitama University \\ Stacey Vye \\ Saitama University
}

Debjani Ray

Tokyo University of Science

This study replicates research by Taguchi, Magid, and Papi (2009) regarding the L2 motivational self system, a framework for understanding second language learning motivation in terms of how learners view themselves as users of the second language (Dörnyei, 2005). The study was of 922 students at a national university in Japan who completed a questionnaire measuring 10 different L2 motivational and attitudinal factors. Correlation analyses and structural equation modeling (SEM) of the data supported the validity of the L2 motivational self system as a culture-independent explanation of the factors comprising L2 motivation. The differences that emerged in the strengths of relationships between factors for our sample compared to the Japanese sample in Taguchi et al. are postulated to be mainly due to differences between the two samples in their socioeconomic background and educational context.

本研究は、L2動機づけ自己システムに関する研究であるTaguchi, Magid, and Papi(2009)を 追試したものである。L2動機づけ自己システムとは、第二言語学習における動機づけを、学習 者が自分を第二言語使用者としてどのように見ているかという観点で理解するための枠組みで

JALT Journal, Vol. 42, No. 1, May 2020 
ある(Dörnyei，2005)。本研究には日本の国立大学生922名が参加した。彼らはL2の動機づけ及 び態度に関わる10個の異なる要因を測定するアンケートに回答した。相関分析と構造方程モデ リング(SEM)を行つた結果、L2動機づけの要因が文化的要因と独立したものであるとするL2動 機づけ自己システムの妥当性が支持された。本研究とTaguchiらの研究で要因間の関係の強さ に違いが生じたのは、主に社会経済的環境及び教育環境の違いが原因だと思われる。

Keywords: culture; ideal self; integrativeness; L2 motivational self system; motivation

7 he L2 motivational self system evolved from the theory in psychology of possible selves posited by Markus and Nurius (1986) in conjunction with prior theories of L2 motivation in second language learning and comprises three key concepts (Dörnyei, 2005, 2009a, 2009b, 2010; Dörnyei \& Ushioda, 2011):

1. the ideal L2 self, or how learners envision themselves ideally using the $\mathrm{L} 2$ in the future;

2. the ought-to L2 self, or the type of L2 user they believe they need to become in order to meet others' expectations while avoiding negative outcomes;

3. L2 learning experience, or attitudes toward the learning environment and experiences with all stakeholders, including achievements (and lack thereof) in that environment.

The L2 motivational self system is an attempt to address issues with Gardner's (1985) integrative model of L2 motivation, which posited that L2 motivation primarily derives from two factors: (a) learners' attitudes toward the language learning situation and (b) their integrativeness, or their interest in learning another language for the purpose of becoming "closer psychologically to the other language community" (Gardner, 2001, p. 12). Gardner (1985) mainly studied learners who were in relatively close proximity to substantial L2 communities (e.g., learners of French in regions of Canada outside of French-speaking Québec). Researchers did not expect this model to fit learners in regions where no substantial L2 community exists (e.g., learners of English in Hungary). However, Dörnyei and Csizér (2002) found that integrativeness appeared to be a primary factor in explaining the L2 motivation of Hungarian learners of English who had little contact with any community of English speakers. In other words, it appeared that the desire to become psychologically closer to an English-speaking community seemed to be a significant motivational factor for learners who had little contact 
with any community of English speakers. Dörnyei and Csizér concluded that the questionnaire items they used to measure integrativeness had actually measured something else: namely, the ideal L2 self. This realization marked the beginning of research into the $\mathrm{L} 2$ motivational self system framework as a replacement for previous models of $\mathrm{L} 2$ motivation.

\section{The L2 Self System in the Japanese University Context}

In Japan, extensive research has been conducted at the tertiary level related to the L2 motivational self system, investigating the L2 learning experience and the ideal L2 self together with international posture (Aubrey, 2014; Aubrey \& Nowlan, 2013; Munezane, 2013; Yashima, 2009, 2013). Additional promising studies on L2 motivation in Japan measure slightly different constructs, including the positive L2 self (Lake, 2013), possible selves (Apple, Falout, \& Hill, 2013), and the micro ideal selves and macro ideal selves (Ueki \& Takeuchi, 2013).

Ryan (2009) conducted a nationwide survey in Japan of 2,397 English learners in order to empirically test the concept of the L2 motivational self system suggested by Csizér and Dörnyei (2005) and Dörnyei, Csizér, and Nemeth (2006) in Japan. Ryan's findings paralleled those of Dörnyei's, indicating that the ideal L2 self better explained his sample's L2 motivation than integrativeness. Specifically, having an affinity for the language and culture of a particular local English-speaking community contributed less to these students' L2 motivation than the desire to see themselves as active in a more global English-speaking community (Ryan, 2009).

At a practical level, educators have explored ways to apply the L2 motivational self system to help learners improve their English abilities through a variety of research practices. Falout (2013) provided suggestions for classroom applications of the L2 motivational self system, Kaneko (2012) presented qualitative research on the system through narrative case studies of university science majors, and Irie and Brewster (2013) described similar qualitative research involving liberal arts majors.

Taguchi, Magid, and Papi (2009) conducted a pivotal study on Dörnyei's (2005) tripartite L2 motivational self system in which they sought to empirically determine the generalizability of the system across varied cultural contexts in Asia by comparing the motivational characteristics of learners of English in Japan, China, and Iran. Their study had three main objectives. 


\section{Objective 1. Test the Viability of the Ideal L2 Self as a Replacement for Integrativeness}

The researchers first explored whether integrativeness might be a key component of L2 motivation in countries lacking a prominent L2 community with which learners could be integrated. Despite the lack of major L2 communities in Iran, China, and Japan, integrativeness strongly predicted the preference for and effort to learn the L2 in those countries, thus confirming the need to replace integrativeness with a construct that could better explain motivation for these contexts. The analysis revealed that the ideal L2 self more strongly predicted preference for and effort to learn the L2 than integrativeness for the three Asian contexts. These findings suggested that the ideal L2 self may be an appropriate replacement for integrativeness.

\section{Objective 2. Test for Two Distinct Types of Instrumentality}

A series of research conducted by Dörnyei and his colleagues (e.g., Dörnyei et al., 2006) derived from the work of Higgins's $(1987,1998)$ found that "the immediate antecedents of this latent variable [i.e., integrativeness] were attitudes toward L2 speakers/community and instrumentality" (Dörnyei, 2005, p. 102). Instrumentality can further be divided into two subconstructs (Dörnyei, 2005):

- promotional instrumentality, which emphasizes the benefits of learning the L2, and

- preventional instrumentality, which emphasizes the disadvantages of failing to learn the L2.

Dörnyei posited that because the ideal self is concerned with what a learner wishes to achieve, it should be closely related to promotional instrumentality. Conversely, the ought-to L2 self should correlate more with preventional instrumentality because it is concerned with what one is obligated to achieve to avoid negative consequences.

Taguchi et al. (2009) found that promotional instrumentality indeed correlated significantly with the ideal L2 self and not with the ought-to L2 self. However, although preventional instrumentality correlated more strongly with the ought-to L2 self as predicted, promotional instrumentality also significantly correlated with the construct, indicating that the instrumentalities may not be as distinct as the theory presumed. 


\section{Objective 3. Test the Validity of Dörnyei's L2 Motivational Self System Across Cultures}

The entire tripartite model, consisting of the ideal L2 self, the ought-to L2 self, and the L2 learning experience, was empirically tested for the first time. Taguchi et al. (2009) hypothesized, based on the work of Dörnyei (2005), that the ideal L2 self would directly affect the criterion measures and indirectly influence them via its effect on attitudes toward language learning. Meanwhile, the ought-to L2 self would directly affect the criterion measures but would not influence the other two components of the framework. Additionally, promotional and preventional instrumentalities, family influence, and attitudes to the L2 culture and community were included as antecedent factors in the model. Structural equation modeling (SEM) confirmed that the patterns of causal relationships between the components of the framework and the criterion measures were valid across contexts, although the strength of the relationships varied depending on the country. The researchers largely attributed the variation to differences between the cultures from which their samples were drawn.

\section{The Importance of Replicating Taguchi et al. (2009)}

Replication research in the social sciences as a methodological approach is an accepted and valuable practice for comparing results with the original study (Porte \& McManus, 2019), and as the research by Taguchi et al. (2009) is one of the earliest large-scale empirical studies on the L2 motivational system, we believe it warrants replication. Traditionally though, several barriers have limited the number of published replication studies in the social sciences, the foremost being the view of replication research as second tier or not original (Porte, 2013). Many studies in Japan have sought to expand on the original L2 motivational self system model by incorporating unique constructs (Apple et al., 2013; Aubrey, 2014; Aubrey \& Nowlan, 2013; Lake, 2013; Munezane, 2013; Ueki \& Takeuchi, 2013; Yashima, 2009, 2013). These studies are valuable in broadening our understanding of L2 motivation and can also be considered what Porte (2013) refers to as conceptual replication studies, in which the main underlying concept in the research remains the same. However, because we view the study by Taguchi et al. as foundational to research into the L2 motivational system, we saw value in replicating it as closely as possible. Also, given the ongoing replication crisis in the social sciences, the old view of replication studies as unoriginal is being replaced by the desire for greater diligence in verifying the claims of seminal research in our field (Porte \& McManus, 2019). Our aim, therefore, is not to point out 
the potential limitations of Taguchi et al., but rather to investigate for further evidence of the validity of their model, while simultaneously uncovering insights from any differences that emerge between our findings and theirs (Porte \& McManus, 2019).

\section{Research Questions}

The present study partially replicates the previously described study by Taguchi et al. (2009; hereinafter, Taguchi et al.). We address three questions, which parallel the above three objectives of Taguchi et al.:

RQ1. Does the ideal L2 self have a stronger relationship with learners' preference for and effort to learn the L2 than integrativeness?

RQ2. Are there two distinct types of instrumentality? If yes, how are they related, and how do they relate with the ideal L2 self and the ought-to L2 self?

RQ3. Does Dörnyei's (2005) tripartite model explain the overall relationships between attitudinal and motivational factors comprising our participants' L2 motivation?

Additionally, we consider the differences in the strengths of relationships between factors for our sample compared to the samples of Taguchi et al. and postulate possible explanations for those differences.

\section{Method}

\section{Participants and Procedure}

This study was conducted in 2013 and involved first-year students in a test preparation course taught by 12 different teachers at a national public university in Japan. The teachers administered a questionnaire to students at the end of the academic year, allowing them approximately 10 minutes in which to complete it. Of the 1,114 students who initially registered for the course, 926 attended class and completed the volunteer questionnaire for this study. Of these 926 students, four students failed to respond to 25 percent of the questionnaire items and were therefore omitted from the study, leaving a total study sample of $N=922$ ( 617 males and 305 females). The breakdown of majors was approximately 20 percent economics, 11 percent liberal arts, 28 percent education, 12 percent science, and 29 percent engineering. All but 13 (1.4 percent) of the students were non-English majors. 


\section{Instruments}

For this study, the same 67 questionnaire items as the questionnaire Taguchi et al. developed for their Japanese participants (the full Japanese version is available in Dörnyei, 2010) were employed with one alteration: Our survey requested the participants' alphanumeric student identification code in place of asking their major with a note that responding to this item was optional. This change allowed us to obtain participants' actual (in addition to perceived) English proficiencies by enabling access to their official Test of English for International Communication (TOEIC) scores from tests taken just before beginning the course and once again upon finishing. Prior to filling out the survey, a separate form was administered to obtain participants' signed consent to our using their survey and course performance data, which included their TOEIC scores (in the case that they provided their student identification codes on the survey), for this research. The form made it clear that participation in the study was voluntary and would have no effect on their grade or standing in the course.

In addition to participant background information, the items on the questionnaire measured 10 different motivational and attitudinal factors. The items included both question and statement types employing a 6-point Likert scale, with "not at all" on the left and "very much" on the right. The Appendix displays the factors, an example item for each factor, and the Cronbach alpha internal consistency reliability coefficients for each item set for both the Japanese participants in Taguchi et al. (2009) and our participants. As shown, there is little difference in the reliability measurements of the items for the two groups of participants, except in the case of attitudes to the L 2 community.

Note that a careful inspection of the item numbers for each factor in Taguchi et al. (p. 75) reveals that only 42 of the total 67 items were used to collect data on the factors. The remaining 25 items were intended to measure other components related to motivation such as fear of assimilation and ethnocentrism. Although these items are not mentioned further in Taguchi et al., they assisted in assessing the validity of the main measures that were employed in the analyses (Taguchi, 2010). Also, note that Taguchi et al. included only 29 of the 42 items developed to collect data on factors in their structural model for their Japanese sample (see p. 83). As detailed in Taguchi et al., the other items were dropped during the measurement model stage of their analysis prior to the creation and testing of their structural model because a valid relationship could not be demonstrated between those items and the attitudinal and/or motivational factors they were supposed to measure. 
Therefore, we also excluded that data from our model as well as omitting from our study the previously mentioned 25 items measuring other components.

\section{Analysis}

To investigate whether the findings of Taguchi et al. were replicable in the Japanese university context, we followed the same procedures they employed and compared our results to theirs. First, we investigated the relationship between integrativeness and the criterion measures. English proficiency as measured by TOEIC scores was included as a secondary criterion measure. Next, we examined the correlations between integrativeness and the ideal L2 self for evidence that the two might be equated. We then investigated correlations to determine if there were two distinct types of instrumentality that corresponded to the two types of self in the L2 motivational self system. Finally, we employed SEM using Amos (Version 21; Arbuckle, 2012) to assess the validity of Taguchi et al.'s model of Dörnyei's (2005) tripartite L2 self system. In particular, we were concerned with the model for Japanese university learners. We addressed missing data in the same way as Taguchi et al. by utilizing the expectation-maximization algorithm.

\section{Results}

\section{Correlation Analyses}

First, we compared the correlations between the ideal L2 self and integrativeness for both studies. Table 1 shows a significant correlation between the ideal L2 self and integrativeness, which is comparable to those found by Taguchi et al., particularly for their non-Japanese samples.

Table 1. A Comparison of Correlations Found Between the Ideal L2 Self and Integrativeness

\begin{tabular}{lccc}
\hline Study & Japan & China & Iran \\
\hline Taguchi et al. (2009) & .59 & .51 & .53 \\
& $(1,534)$ & $(1,328)$ & $(2,029)$ \\
Present study & .50 & - & - \\
& $(922)$ & & \\
\hline
\end{tabular}


Congruent with the findings of Taguchi et al., the criterion measures correlated significantly with both integrativeness and the ideal L2 self in the present study. Table 2 further shows that the criterion measures are more strongly correlated with the ideal L2 self than with integrativeness.

Table 2. A Comparison of Correlations Found Between the Criterion Measures and the Ideal L2 Self and Integrativeness Respectively

\begin{tabular}{llccc}
\hline Study & Construct & Japan & China & Iran \\
\hline \multirow{2}{*}{ Taguchi et al. (2009) } & Ideal L2 self & .68 & .55 & .61 \\
& Integrativeness & .64 & .52 & .58 \\
\multirow{2}{*}{ Present study } & Ideal L2 self & .60 & - & - \\
& Integrativeness & .51 & - & - \\
\hline
\end{tabular}

Note. All correlations are significant at the $p<.01$ level.

The data revealed that, although both integrativeness and the ideal L2 self correlated significantly with learners' English proficiency as measured by averaged pre- and post-TOEIC scores for the 437 participants who volunteered to identify themselves, the correlation was stronger with the ideal L2 self, $r=.24, p<.001$, than with integrativeness, $r=.15, p=.002$. Although these correlations are both rather weak, it is important to note that participants' own self-assessments of their proficiency had only a slightly higher correlation with their ideal L2 self, $r=.28, p<.001$, and with integrativeness, $r=.20, \mathrm{p}<.001$. Meanwhile, neither self-assessed proficiency nor proficiency as measured by the TOEIC correlated significantly with the ought-to self, $r=.05, p=.297$ and $r=-.02, p=.677$ respectively.

Next, we examined the relationships between ideal L2 selves and oughtto L2 selves, promotional instrumentality, and preventional instrumentality. Our results are displayed in Table 3 and those of Taguchi et al. are presented in Table 4. Comparing the findings of the two studies, we see that, in both cases, instrumentality promotion correlated more highly with the ideal L2 self than with the ought-to L2 self, and instrumentality prevention correlated more highly with the ought-to L2 self than with the ideal L2 self. The difference between our findings and Taguchi et al.'s findings lies in the near equal correlations between the two instrumentalities and the ought-to L2 self, whereas theory predicts that preventional instrumentality should have a stronger relationship with the ought-to L2 self than promotional 
instrumentality. This finding parallels the results for the Chinese and Iranian samples in Taguchi et al.

Table 3. Relationships Between Instrumentalities and Ideal L2 and Ought-to L2 Selves

\begin{tabular}{lccc}
\hline Construct & Ideal L2 self & Ought-to L2 self & $\begin{array}{c}\text { Promotional } \\
\text { instrumentality }\end{array}$ \\
\hline $\begin{array}{l}\text { Ought-to L2 self } \\
\begin{array}{l}\text { Promotional } \\
\text { instrumentality }\end{array}\end{array}$ & $.35^{* *}$ & - & - \\
$\begin{array}{l}\text { Preventional } \\
\text { instrumentality }\end{array}$ & $.06^{* *}$ & $.35^{* *}$ & - \\
${ }^{*} p<.05$, two-tailed. ${ }^{* *} p<.01$, two-tailed. & $.37^{* *}$ & $.47^{* *}$ \\
\end{tabular}

Table 4. Relationships Between Instrumentalities in Taguchi et al. (2009)

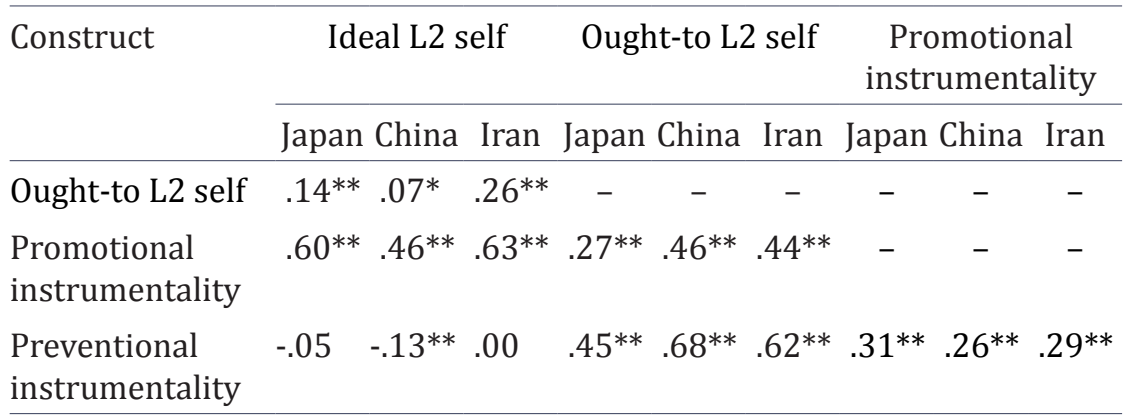

Note. Adapted from "The L2 Motivational System Among Japanese, Chinese, and Iranian Learners of English: A Comparative Study," by T. Taguchi, M. Magid, \& M. Papi, in Z. Dörnyei and E. Ushioda (Eds), Motivation, Language Identity and the L2 Self (p. 79), 2009, Multilingual Matters (https://doi.org/10.21832/9781847691293-005). Copyright 2009 by Tatsuya Taguchi, Michael Magid, and Mostafa Papi. Reprinted with permission.

\section{Structural Equation Modeling Analysis}

The validity of the L2 motivational self system and related attitudinal and motivational factors was evaluated by applying it to the data from our sample and examining the path coefficients and goodness-of-fit measures. 
To do this, we tested a structural model identical to the one Taguchi et al. developed for their Japanese students (see Figure 1 for their original model). As did their model, our model (see Figure 2) combines attitudes to the L2 community and cultural interest into a single variable, moving one of the scales used for the ought-to L2 self over to be included in a family influence variable. The model includes the ideal L2 self, ought-to L2 self, attitudes to learning English, and the criterion measures as latent variables.

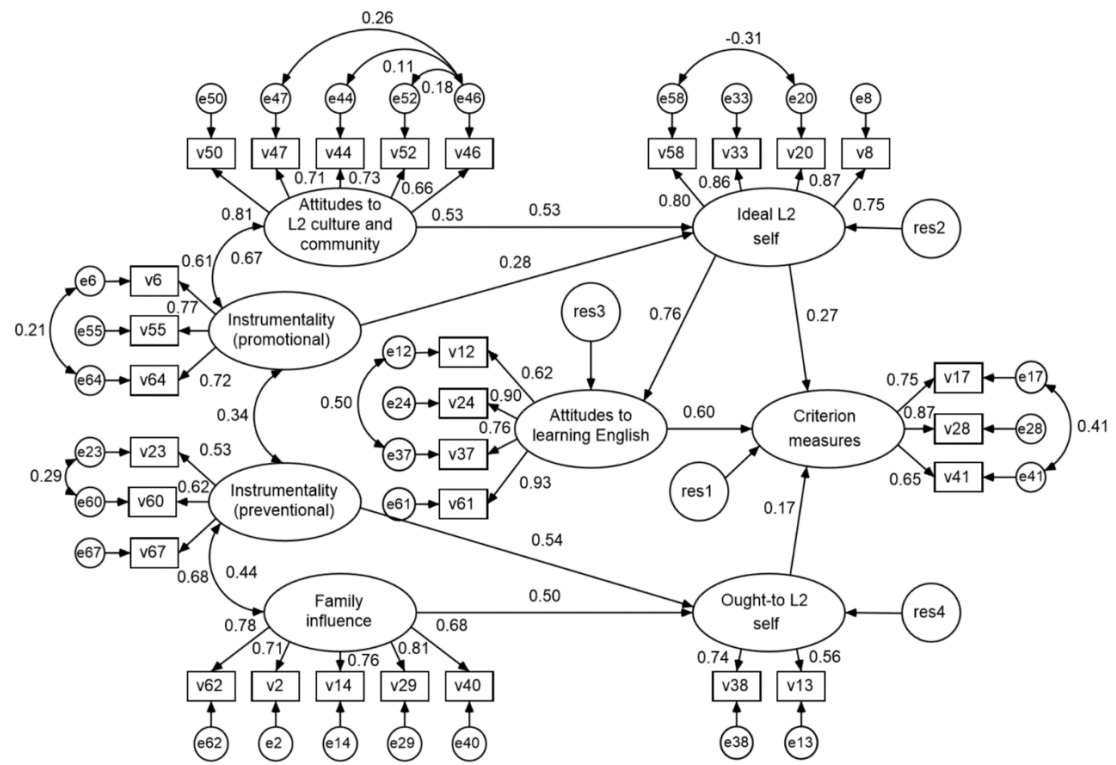

Figure 1. Taguchi et al.'s (2009) original model of the L2 self system with standardized estimates for their Japanese university student sample. Paths indicate hypothesized causal relationships. $\mathrm{e}=$ error variance; res = residual; $\mathrm{v}=$ variable (questionnaire item). From "The L2 Motivational System Among Japanese, Chinese, and Iranian Learners of English: A Comparative Study," by T. Taguchi, M. Magid, \& M. Papi, in Z. Dörnyei and E. Ushioda (Eds), Motivation, Language Identity and the L2 Self (p. 83), 2009, Multilingual Matters (https://doi.org/10.21832/9781847691293-005). Copyright 2009 by Tatsuya Taguchi, Michael Magid, and Mostafa Papi. Reprinted with permission. 


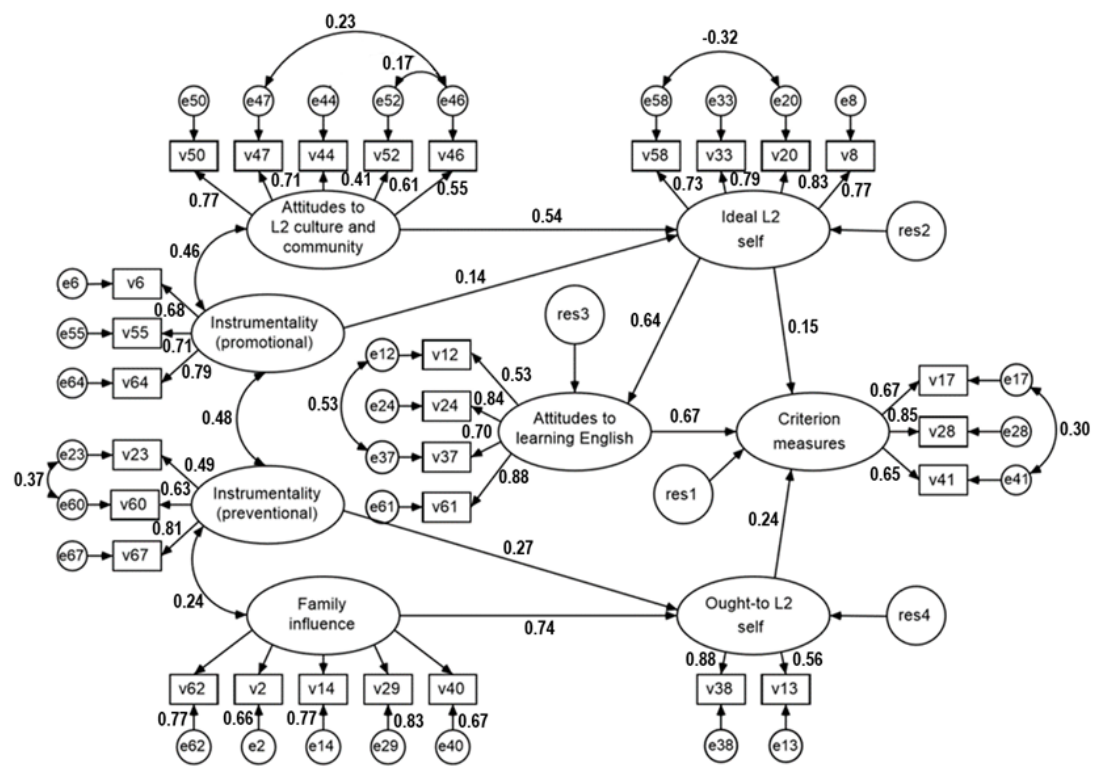

Figure 2. Our model of the L2 motivational self system derived by applying the original model for Japanese students by Taguchi et al. (2009) to our sample with standardized estimates. Paths indicate hypothesized causal relationships and their strengths. $\mathrm{e}=$ error variance; res = residual covariance; $\mathrm{v}$ $=$ variable (questionnaire item). $N=922$. All path coefficients are significant at $p<.001 . \chi^{2}(360)=1551.40, p<.001$, GFI $=.893$; CFI $=.905$; RMSEA $=.06$.

With the exception of the removal of the error covariances between e6 and e64 and between e44 and e46 due to their nonsignificance, our model is structured the same as the original model for Japanese students by Taguchi et al. All paths were significant at the $p<.001$ level, with an expectedly large chi-square of $\chi^{2}(360)=1551.40, p<.001$. GFI, CFI, and RMSEA values $(.89, .91$, and .06 respectively) further indicated the model's goodness of fit. Although the GFI is lower than hoped for, the CFI and RMSEA are both within traditionally acceptable ranges (Hooper, Coughlan, \& Mullen, 2008). It is possible that by altering the paths or dropping items, we could have produced more favorable goodness-of-fit indices, but our aim was to replicate the model of Taguchi et al. rather than to produce a new model. Therefore, we have refrained from such alterations. 
Figure 3 shows how, overall, coefficients of the model matched those obtained by Taguchi et al. One notable difference was that the ought-to L2 self had a stronger direct influence on the criterion measures than the ideal L2 self. The next section discusses this and other differences further.

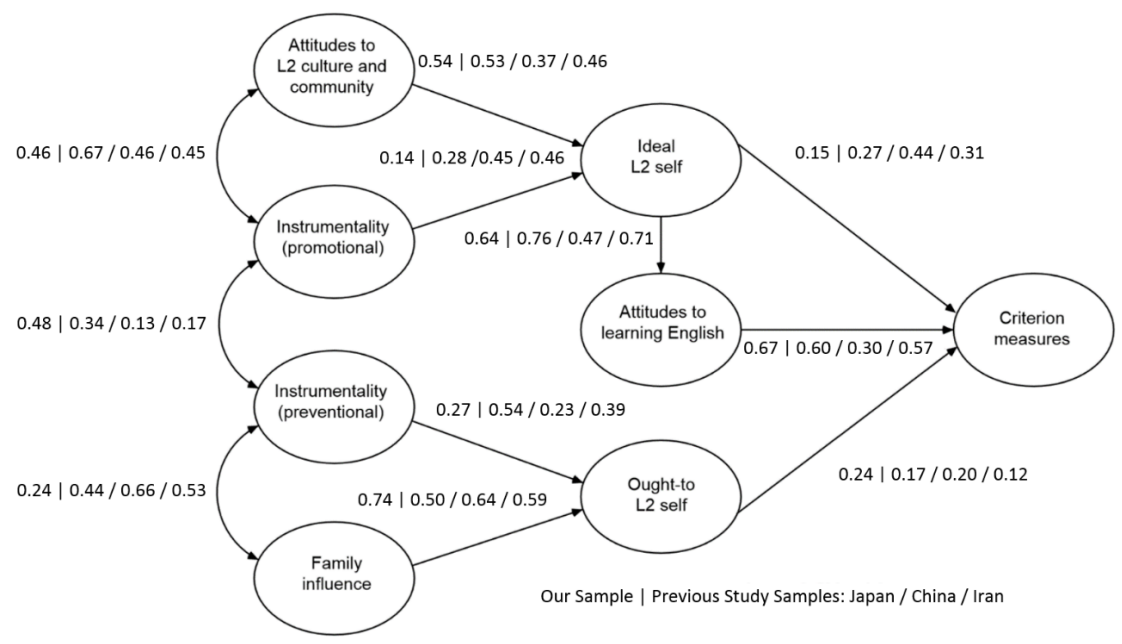

Figure 3. Comparing coefficients in our study to those of Taguchi et al. (2009). Adapted from "The L2 Motivational System Among Japanese, Chinese, and Iranian Learners of English: A Comparative Study," by T. Taguchi, M. Magid, \& M. Papi, in Z. Dörnyei and E. Ushioda (Eds), Motivation, Language Identity and the L2 Self (p. 86), 2009, Multilingual Matters (https://doi. org/10.21832/9781847691293-005). Copyright 2009 by Tatsuya Taguchi, Michael Magid, and Mostafa Papi. Reprinted with permission.

\section{Discussion}

\section{Findings in Support of the Tripartite Model of L2 Motivation}

In our study, we first sought to determine whether the ideal L2 self is a more effective construct than integrativeness for explaining L2 motivation in diverse contexts. As explained in the introduction, integrativeness should not play a role in determining learner motivation in a country such as Japan, because there is no substantial subpopulation of English-as-a-first-language users with which a learner could hope to integrate. However, as in Taguchi et al. and Dörnyei et al. (2006), the higher our Japanese participants' motiva- 
tion was, the more apparent integrativeness they seemed to possess. Also, as in Taguchi et al., our sample's apparent integrativeness was highly correlated with the ideal L2 self, and the ideal L2 self correlated more highly with learners' preference for and effort to learn English than did integrativeness. This result paralleled our additional finding that the ideal L2 self was a better predictor of L2 proficiency as measured by the TOEIC than integrativeness.

At the same time, the lack of a significant correlation between the oughtto self and both self-assessed proficiency and proficiency as measured by the TOEIC shows that the ought-to self is not a predictor of L2 learning achievement. This is relatively unsurprising as the ought-to self primarily derives from the perceived expectations of a learner's family and society. Although the influence of the ought-to self may increase as a learner fails to achieve expected learning outcomes, implying a negative correlation, the ought-to self should neither increase nor decrease as a learner achieves at or above the expected level of learning. This explanation is supported by a significant negative correlation that emerged between TOEIC scores and the ought-to self for only the lower performing half of those in our sample whose scores were available $(n=219), r=-.15, p=.026$, whereas the correlation for the upper half $(n=218)$ remained insignificant at $r=$ $.02, p=.803$. Thus, despite our finding that the ought-to self had a stronger influence on the criterion measures than the ideal L2 self for our sample, no consistent overall relationship emerged between the ought-to self and actual L2 proficiency.

The rather surprising weakness of the correlation-between the TOEIC scores and the ideal L2 self as well as between self-assessed proficiency and the ideal L2 self-may suggest that motivation is not as strong a predictor of proficiency as many would assume. Vandergrift (2005) obtained similarly weak correlations when measuring the relationship between motivation and L2 listening proficiency: The strongest and only significant correlation was -.30 with amotivation (correlations with intrinsic and extrinsic motivation were .12 and .16 respectively). Upon reflection, though, we note that the relationship between proficiency and motivation may not always be a positive one, nor must it always be motivation that affects proficiency. The reverse is also possible. Someone who achieves a high proficiency test score, for example, may become complacent with their L2 ability and consequently experience a drop in their motivation. Meanwhile, another learner might be motivated by a low test score to do better the next time. Alternatively, the student who gets the high score might become more motivated having seen 
their efforts pay off on the test, while the student who got the low score might see it as evidence that, no matter how hard they try, they can never get better at the L2. Given this complex dynamic, the weak positive correlation between the ideal L2 self and TOEIC score is less surprising. Regardless, we concur with Taguchi et al. that the ideal L2 self is a more conceptually sound and empirically powerful construct than integrativeness for explaining L2 motivation.

Similar to Taguchi et al., we found that the ideal L2 self was strongly related to promotional instrumentality, but had no significant relationship with preventional instrumentality. Likewise, the ought-to L2 self was more strongly related with preventional instrumentality than it was with promotional. However, the findings for our participants differed from Taguchi et al. in that the correlation between promotional instrumentality and the ought-to L2 self-though lower than that of preventional instrumentality and the ought-to L2 self-was nearly equal.

Taguchi et al.'s Chinese and Iranian samples also had relatively higher correlations between promotional instrumentality and the ought-to L2 self. Taguchi et al. attributed these to socioeconomic factors in their countriesspecifically to higher family pressure to advance their careers compared to their Japanese counterparts. Due to this pressure, the responses of these two groups to career-related instrumentality promotion items reflected their families' interests as much as their own (i.e., reflecting their ought-to L2 self). A similar explanation may be applied to the Japanese sample in this study. Family influence played an even more central role in determining our participants' L2 motivation than it did for the Chinese sample of Taguchi et al. for whom family influence was the strongest.

The overall model of L2 motivation tested by Taguchi et al. proved valid for our sample as well. We found that L2 motivation, perceived promotional instrumentality of the L2, and learners' attitudes toward the L2 culture influenced their ideal L2 self. Their ideal L2 self, in turn, had a direct effect on their preference for and effort to learn the L2 while indirectly influencing attitudes toward learning the L2. Concurrently, family influence and the perceived preventional instrumentality of the L2 affected learners' oughtto L2 self. The learners' ought-to L2 self had a direct effect on preference for and effort to learn the L2. Also, echoing the findings of Taguchi et al. regarding their Japanese sample and in contrast with their Iranian and Chinese samples, our participants' attitudes toward the L2 culture had a much stronger impact on their ideal L2 self than did the promotional instrumentality of the L2. We also found that, similar to their Japanese and 
Iranian samples, our sample exhibited disproportionate indirect influence of the ideal L2 self on the preference for and effort to learn the L2.

\section{Exploring Differences in the Model}

The findings of the current study regarding the overall tripartite model correspond to those of Taguchi et al. with three notable differences in the strength of relations between factors. The first has already been discussed: that is, the relatively strong correlation between promotional instrumentality and the ought-to L2 self, which was more similar to the non-Japanese samples of Taguchi et al. than it was to their Japanese sample. Second, the influence of family on the ought-to L2 self exceeded that of any of the samples in the study by Taguchi et al. and was disproportionately stronger than the influence of preventional instrumentality. Third, unlike any of the samples in Taguchi et al., the influence of the ought-to L2 self on the preference for and effort to learn English surpassed the direct influence of the ideal L2 self. The present sample's socioeconomic background and the type of English course they were enrolled in may help to explain these differences.

Considering differences in institutional context may provide insights into the disproportionate influence of the family as well as that of the ought-to L2 self. Whereas Taguchi et al. involved eight universities, six of which were private (see Taguchi, 2010), our study was conducted at a single public university. Public universities in Japan are more affordable and generally more competitive than private universities. The combination of affordability and competitiveness of the university in our study makes it reasonable to assume that, compared to the sample of Taguchi et al., a larger portion of students in our sample were from families with modest incomes who were encouraged to study long hours for a better chance of entering the university. Irie and Brewster (2013) found that such family influences due to economic pressures coincided with a university student's inability to envision a robust ideal self. Overall, similar to the Chinese and Iranian samples of Taguchi et al., the students in our sample are more likely to see the promotional aspects of learning English as a means of helping them fulfill obligations to their family, which in turn impacts their ought-to L2 self.

The type of English course in which the participants were enrolled, as well as the proportion of participants majoring in English in our study, also differed from Taguchi et al.. The students in their sample took various English courses, including compulsory and elective, general, and contentbased (Taguchi, personal communication, October 12, 2019). Conversely, all of our participants experienced a compulsory English course that focused 
mainly on developing business-related test-taking skills as opposed to actual language proficiency or knowledge of content. Furthermore, approximately $21 \%$ of Taguchi et al.'s sample were English majors; in our study they were less than two percent. Ueki and Takeuchi (2013) found that ideal L2 self influence on motivated behavior was stronger for English majors compared to non-English majors, while the ought-to L2 self influence was stronger for non-English majors than for those who majored in English. Students majoring in English are more likely to see learning the language as careeroriented and identity-affirming behavior, whereas non-English majors are less likely to be able to connect learning the L2 with career goals or a positive future self-image. This is especially so in the case of our sample, whose English course content was largely unrelated to their fields of study, making it more difficult for them to envision how they might ideally use the L2 in the future. This may have diminished their sense of ideal L2 self and thereby weakened its influence on their preference for and effort to learn the L2. The findings of several studies support this explanation, providing evidence for the demotivating influence of nonrelevant EFL content (Edsall \& Saito, 2012; Falout, Elwood, \& Hood, 2009; Kikuchi, 2009, 2013; Kikuchi \& Browne, 2009; Sakai \& Kikuchi, 2009).

Given that the three samples in the study by Taguchi et al. were each from a different culture, it is understandable that the researchers attributed the differences in strengths between motivational factors in their samples to differences in culture. However, we found that, with regard to the strengths of relations between certain factors in the model, our sample had more in common with the non-Japanese samples of Taguchi et al. than with their Japanese sample. Therefore, we hypothesize that other differences such as in the socioeconomic and educational context may also play an important role in determining the specific strengths of relationships between factors. Further research is needed to determine whether this hypothesis is empirically supported.

\section{Practical Implications}

Our study adds to the growing evidence that the L2 motivational self system applies to learners across cultures. Our findings also suggest that curricular variation may lead to differences in the strengths of relations between factors within that system. Therefore, it is worthwhile to consider how the framework can inform our teaching practice and how we may be able to positively influence our students' motivational dynamics through making proactive changes to their educational context. 
The ideal L2 self, as well as the ought-to L2 self, significantly influence preference for and effort to learn the language. Thus, finding ways to help learners develop, clarify, and strengthen these L2 selves should lead to an increase in their motivation. Based on our findings, one way to strengthen learners' L2 selves might be to revise their English curriculum to align more with their projected career paths, for example, introducing or increasing content-based English courses in core subjects of their majors.

Another approach involves the direct application of the L2 motivational self system in the language classroom. Dörnyei (2009b) and Mackay (2014) provided general guidelines for how students can develop and realize their L2 selves. They described a process by which students envision, clarify, and strengthen both their ideal L2 self and ought-to L2 self while setting and working toward goals that are in line with those selves. Meanwhile, Hadfield and Dörnyei (2013) offered explicit techniques for developing students' L2 selves. These techniques employ classroom activities in which students use mental imagery to develop their vision of what kind of person they would like to become. Arnold, Puchta, and Rinvolucri (2007) provided activities that, though not always targeting the development of the L2 selves, seek to strengthen learners' ability to envision possible selves. Magid and Chan (2012) and Murray (2011) found that learners strengthened their visions of their L2 selves with such techniques as imagery, goal setting, and selfregulation. Dörnyei and Kubanyiova (2014) offered practical imagery tools for teachers to strengthen learners' sense of their ideal L2 selves that include the guided use of journals, virtual platforms, group learning visions, reality checklists, and mapping out plans for success. Dörnyei and Kubanyiova also addressed the motivational needs of teachers through vision techniques that contribute to the overall motivational strength and resolve of the stakeholders in the language classroom.

\section{Conclusion}

In this study, we sought to further confirm the generalizability of the L2 motivational self system through partially replicating the research of Taguchi et al. (2009) and to explore any differences between their samples and ours. Specifically, we investigated, first, whether the ideal L2 self is a better predictor of L2 motivation than integrativeness, and second, whether there are two distinct types of instrumentality corresponding to the two types of the L2 self (Dörnyei, 2005). Third, we investigated whether the tripartite model of Taguchi et al. sufficiently explains the relationships between motivational 
and attitudinal factors that comprised our participants' L2 motivation. Finally, we explored the differences that emerged in the strengths of relations between motivational factors for our sample compared to those of Taguchi et al.

Our results support the findings of Taguchi et al. that integrativeness among EFL populations may be the ideal L2 self imperfectly measured. The ideal L2 self, although correlated with integrativeness, is a more accurate and theoretically sound predictor of L2 motivation than integrativeness. The ideal L2 self also has a higher correlation with both perceived and actual proficiency than integrativeness, although these correlations are weaker than expected. Meanwhile, promotional instrumentality has a strong relationship with the ideal L2 self, whereas the relationship between preventional instrumentality and the ideal L2 self is comparatively weak. These findings, combined with the results of our SEM analysis, indicate that the tripartite model of L2 motivation used by Taguchi et al. also sufficiently describes our sample.

Though our findings provide overall support for Taguchi et al.'s model, differences emerged in the strength of the relationships between certain factors in the model. Foremost was the ought-to L2 self's stronger direct influence on preference for and effort to learn the L2 compared with that of the ideal L2 self. Additionally, family influence more strongly contributed to the ought-to L2 self than it did for any of Taguchi et al.'s samples. Furthermore, the relatively strong correlation between promotional instrumentality and the ought-to L2 self more closely resembled the earlier study's Chinese and Iranian samples than its Japanese sample. We posit that differences in socioeconomic background and educational context between our sample and the Japanese sample in the previous study explain these differences, but further research is necessary before this explanation can be accepted or rejected.

To conclude, our study provides evidence supporting the explanatory power of the tripartite model of the L2 motivational self originally tested by Taguchi et al. Overall, the framework of the L2 motivational self appears to provide a robust and culture-independent explanation of the factors comprising L2 motivation and their interrelationships. Finally, the differences we found suggest the limitations of culture-based explanations for variations between samples, opening the door for further research into the role of other contextual factors in the L2 motivational self system. 


\section{Acknowledgments}

We would like to thank Ken Oikawa for his invaluable assistance in translating the abstract for this paper and Nobuko Hagiuda for her expert instruction and advice regarding SEM analysis.

Leander Hughes is an associate professor at Saitama University. His research interests include the psychology of language learning, vocabulary acquisition, reading in a second language, and CALL.

Stacey Vye is an associate professor at Saitama University. Her research interests include university students' perceptions of English language learning and learner and teacher autonomy.

Debjani Ray is employed at Tokyo University of Science. She is interested in English language education and social education, specifically, women's empowerment.

\section{References}

Arbuckle, J. L. (2012). Amos (Version 21) [Computer Program]. Chicago, IL: IBM SPSS. Apple, M. T., Falout, J., \& Hill, G. (2013). Exploring classroom-based constructs of EFL motivation for science and engineering majors in Japan. In M. T. Apple, D. Da Silva, \& T. Fellner (Eds.), Language learning motivation in Japan (pp. 54-74). https://doi.org/10.21832/9781783090518-006

Arnold, J., Puchta, H., \& Rinvolucri, M. (2007). Imagine that! Mental imagery in the EFL classroom. Rum, Austria: Helbling Languages.

Aubrey, S. (2014). Development of the L2 motivational self system: English at a university in Japan. JALT Journal, 36, 153-174. Retrieved from https://jalt-publications.org/sites/default/files/pdf-article/jj2014b-art1.pdf

Aubrey, S., \& Nowlan, J. P. (2013). Effect of intercultural contact on L2 motivation: A comparative study. In M. T. Apple, D. Da Silva, \& T. Fellner (Eds.), Language learning motivation in Japan (pp. 129-151). https://doi.org/10.21832/9781783090518-010

Csizér, K., \& Dörnyei, Z. (2005). The internal structure of language learning motivation and its relationship with language choice and learning effort. The Modern Language Journal, 89, 19-36. https://doi.org/10.1111/j.0026-7902.2005.00263.x

Dörnyei, Z. (2005). The psychology of the language learner: Individual differences in second language acquisition. Mahwah, NJ: Lawrence Erlbaum Associates. 
Dörnyei, Z. (2009a). The L2 motivational self system. In Z. Dörnyei \& E. Ushioda (Eds.), Motivation, language identity and the L2 self (pp. 9-42). https://doi.org/10.21832/9781847691293-003

Dörnyei, Z. (2009b). The psychology of second language acquisition. Oxford, England: Oxford University Press.

Dörnyei, Z. (2010). Questionnaires in second language research: Construction, administration, and processing (2nd ed.). London, England: Routledge.

Dörnyei, Z., \& Csizér, K. (2002). Some dynamics of language attitudes and motivation: Results of a longitudinal nationwide survey. Applied Linguistics, 23, 421-462. https://doi.org/10.1093/applin/23.4.421

Dörnyei, Z., Csizér, K., \& Nemeth, N. (2006). Motivation, language attitudes, and globalization: A Hungarian perspective. Clevedon, England: Multilingual Matters.

Dörnyei, Z., \& Kubanyiova, M. (2014). Motivating learners, motivating teachers: Building vision in the language classroom. Cambridge, England: Cambridge University Press.

Dörnyei, Z., \& Ushioda, E. (2011). Teaching and researching: Motivation (2nd ed.) London, England: Longman.

Edsall, D., \& Saito, Y. (2012). The motivational benefits of content. OnCUE Journal, 6(2), 66-94. Retrieved from https://jaltcue.org/journal_6.2

Falout, J. (2013). Prospecting possible EFL selves. The Language Teacher, 37(5), 4549. Retrieved from https://jalt-publications.org/tlt/articles/3354-prospectingpossible-efl-selves

Falout, J., Elwood, J., \& Hood, M. (2009). Demotivation: Affective states and learning outcomes. System, 37, 403-417. https://doi.org/10.1016/j.system.2009.03.004

Gardner, R. C. (1985). Social psychology and second language learning: The role of attitudes and motivation. London, England: Edward Arnold.

Gardner, R. C. (2001, February). Integrative motivation: Past, present and future. Distinguished Lecturer Series, Temple University Japan, Tokyo. Retrieved from http://publish.uwo.ca/ gardner/docs/GardnerPublicLecture1.pdf

Hadfield, J., \& Dörnyei, Z. (2013). Motivating learning. Harlow, England: Pearson.

Higgins, E. T. (1987). Self-discrepancy: A theory relating self and affect. Psychological Review, 94, 319-340. https://psycnet.apa.org/doi/10.1037/0033-295X.94.3.319

Higgins, E. T. (1998). Promotion and prevention: Regulatory focus as a motivational principle. Advances in Experimental Social Psychology, 30, 1-46. https://doi.org/10.1016/S0065-2601(08)60381-0 
Hooper, D., Coughlan, J., \& Mullen, M. R. (2008). Structural equation modeling: Guidelines for determining model fit. Electronic Journal of Business Research Methods, 6, 53-60.

Irie, K., \& Brewster, D. R. (2013). One curriculum, three stories: Ideal L2 self and L2self-discrepancy profiles. In M. T. Apple, D. Da Silva, \& T. Fellner (Eds.), Language learning motivation in Japan (pp. 110-128). https://doi.org/10.21832/9781783090518-009

Kaneko, E. (2012). On the motivation of science majors learning English as a foreign language: A case study from Japan. OnCUE Journal, 6(2), 3-26. Retrieved from https://jaltcue.org/journal_6.2

Kikuchi, K. (2009). Listening to our learners' voices: What demotivates Japanese high school students? Language Teaching Research, 13, 453-471. https://doi.org/10.1177/1362168809341520

Kikuchi, K. (2013). Demotivators in the Japanese EFL context. In M. T. Apple, D. Da Silva, \& T. Fellner (Eds.), Language learning motivation in Japan (pp. 206-224). https://doi.org/10.21832/9781783090518-014

Kikuchi, K., \& Browne, C. (2009). English educational policy for high schools in Japan: Ideals vs. reality. RELC Journal, 40, 172-191. https://doi.org/10.1177/0033688209105865

Lake, J. (2013). Positive L2 self: Linking positive psychology with L2 motivation. In M. T. Apple, D. Da Silva, \& T. Fellner (Eds.), Language learning motivation in Japan (pp. 225-244). https://doi.org/10.21832/9781783090518-015

Mackay, J. (2014). Applications and implications of the L2 motivational self system in a Catalan EFL context. In K. Csizér \& M. Magid (Eds.), The impact of selfconcept on language learning (pp. 377-400). https://doi.org/10.21832/9781783092383-021

Magid, M., \& Chan, L. (2012). Motivating English learners by helping them visualize their ideal L2 self: Lessons from two motivational programmes. Innovation in Language Learning and Teaching, 6, 113-125. https://doi.org/10.1080/17501229.2011.614693

Markus, H., \& Nurius, P. (1986). Possible selves. American Psychologist, 41, 954-969. https://psycnet.apa.org/doi/10.1037/0003-066X.41.9.954

Munezane, Y. (2013). Motivation, ideal L2 self and valuing of global English. In M. T. Apple, D. Da Silva, \& T. Fellner (Eds.), Language learning motivation in Japan (pp. 152-168). https://doi.org/10.21832/9781783090518-011 
Murray, G. (2011). Imagination, metacognition, and the L2 self in a self-access learning environment. In G. Murray, X. Gao, \& T. Lamb (Eds.), Identity, motivation, and autonomy in language learning (pp. 75-90). https://doi.org/10.21832/9781847693747-007

Porte, G. (2013). Who needs replication? CALICO Journal, 30, 10-15. https://doi.org/10.11139/cj.30.1.10-15

Porte, G., \& McManus, K. (2019). Doing research in applied linguistics. New York, NY: Routledge.

Ryan, S. (2009). Self and identity in L2 motivation in Japan: The ideal L2 self and Japanese learners of English. In Z. Dörnyei \& E. Ushioda (Eds.), Motivation, language identity and the L2 self (pp. 120-143). https://doi.org/10.21832/9781847691293-007

Sakai, H., \& Kikuchi, K. (2009). An analysis of demotivators in the EFL classroom. System, 37, 57-69. https://doi.org/10.1016/j.system.2008.09.005

Taguchi, T. (2010). The motivational self system among Japanese learners of English: A mixed-method approach (Unpublished doctoral dissertation). University of Nottingham, Nottingham, England.

Taguchi, T., Magid, M., \& Papi, M. (2009). The L2 motivational system amongst Japanese, Chinese, and Iranian learners of English: A comparative study. In Z. Dörnyei \& E. Ushioda (Eds.), Motivation, language identity and the L2 self (pp. 66-97). https://doi.org/10.21832/9781847691293-005

Ueki, M., \& Takeuchi, O. (2013). Forming a clearer image of the ideal L2 self: The L2 motivational self system and learner autonomy in a Japanese EFL context. Innovation in Language Learning and Teaching, 7, 238-252. https://doi.org/10.1080/17501229.2013.836205

Vandergrift, L. (2005). Relationships among motivation orientations, metacognitive awareness and proficiency in L2 listening. Applied Linguistics, 26, 70-89. https://doi.org/10.1093/applin/amh039

Yashima, T. (2009). International posture and the ideal L2 self in the Japanese EFL context. In Z. Dörnyei \& E. Ushioda (Eds.), Motivation, language identity and the L2 self (pp. 144-163). https://doi.org/10.21832/9781847691293-008

Yashima, T. (2013). Imagined L2 selves and motivation for intercultural communication. In M. T. Apple, D. Da Silva, \& T. Fellner (Eds.), Language learning motivation in Japan (pp. 35-53). https://doi.org/10.21832/9781783090518-005 


\section{Appendix}

Questionnaire Factors, Example Items, and Cronbach's Alpha Coefficients

\begin{tabular}{|c|c|c|c|}
\hline Factor name & Example item & $\begin{array}{r}\alpha \text { (Taguchi } \\
\text { et al. 2009) }\end{array}$ & $\begin{array}{l}\alpha \text { (Present } \\
\text { study) }\end{array}$ \\
\hline $\begin{array}{l}\text { Criterion } \\
\text { measures }\end{array}$ & $\begin{array}{l}\text { I am working hard at learning } \\
\text { English. }\end{array}$ & .83 & .78 \\
\hline Ideal L2 self & $\begin{array}{l}\text { I can imagine myself living } \\
\text { abroad and having a discussion } \\
\text { in English. }\end{array}$ & .89 & .81 \\
\hline Ought-to L2 self & $\begin{array}{l}\text { Learning English is necessary } \\
\text { because people surrounding me } \\
\text { expect me to do so. }\end{array}$ & .76 & .80 \\
\hline Family influence & $\begin{array}{l}\text { My parents encourage me to } \\
\text { study English. }\end{array}$ & .83 & .81 \\
\hline $\begin{array}{l}\text { Promotional } \\
\text { instrumentality }\end{array}$ & $\begin{array}{l}\text { Studying English is important } \\
\text { for me because with English I } \\
\text { can work globally. }\end{array}$ & .82 & .79 \\
\hline $\begin{array}{l}\text { Preventional } \\
\text { instrumentality }\end{array}$ & $\begin{array}{l}\text { I have to learn English because } \\
\text { without passing the English } \\
\text { course I cannot graduate. }\end{array}$ & .73 & .72 \\
\hline $\begin{array}{l}\text { Attitudes to } \\
\text { learning English }\end{array}$ & I really enjoy learning English. & .90 & .85 \\
\hline Cultural interest & $\begin{array}{l}\text { Do you like the music of } \\
\text { English-speaking countries (e.g. } \\
\text { pop music)? }\end{array}$ & .77 & .79 \\
\hline $\begin{array}{l}\text { Attitudes to L2 } \\
\text { Community }\end{array}$ & $\begin{array}{l}\text { Do you like the people who live } \\
\text { in English-speaking countries? }\end{array}$ & .86 & 67 \\
\hline integrativeness & $\begin{array}{l}\text { How much would you like to } \\
\text { become similar to the people } \\
\text { who speak English? }\end{array}$ & .64 & .56 \\
\hline
\end{tabular}

